\title{
Inicjatywa Trójmorza w świetle teorii realizmu. Polityczne aspekty nowej formy współpracy dwunastu państw
}

\author{
The Three Seas Initiative in the light of the theory of realism: \\ The political aspects of the new form of cooperation \\ between the twelve countries
}

The aim of the article is to explain the motives of cooperation within the framework of the Three Seas Initiative in the light of the theory of realism, including its various trends. The creation of the Three Seas Initiative can be considered as an example of international cooperation whose aim is to satisfy the interests of the states which form the initiative and compete with each other. What are the interests of the United States, Germany and the Central and Eastern European countries? Does the Three Seas Initiative integrate or disintegrate the European Union (EU)? Can it be treated as an attempt to balance growing powers, such as Germany? What is the effect of changing the balance of power in the regional and global dimension? How can classical realism, structural realism, neorealism and neoclassical realism help to answer these questions?

On the one hand, this group is considered to be a manifestation of Poland's desire to strengthen its position and fulfil the function of the leader of Central and Eastern Europe under the patronage of the United States by weakening ties with Germany. It is also pointed out that the declared goals of the Three Seas Initiative are to strengthen the EU and even the entire Euro-Atlantic community. The United States consistently supports this initiative, which is in line with its interests, particularly in the sphere of energy. In 2018, the European Commission unexpectedly recognised that the Three Seas Initiative complemented the activities of the European Union and Germany declared its willingness to join the group.

The theory of realism explains well the motives of competition and conflicts, focusing on the aspect of security and power, and admitting the primacy of the political sphere. When explaining cooperation in the framework of the Three Seas Initiative, this approach faces difficulties. In this case, the emphasis on the declarative plane has been shifted to the economic dimension. Nevertheless, the political significance of this new initiative is increasing. At the summit in Bucharest, its priorities included strengthening the transatlantic community. For the countries of Central and Eastern Europe, the transatlantic vision of the world seems much safer than its disintegration and the creation of a post-Atlantic world. 
In the case of further unfavourable transformations of the international order, an increase in the sense of threat may lead to strengthening the political dimension of the Three Seas Initiative as a tool for building relations between Central and Eastern Europe and the United States. The article is meant to constitute an introduction and an incentive to use the theory of realism in further research on this initiative.

Keywords: Three Seas Initiative, Central and Eastern Europe, Central Europe, United States, Germany, European Union

Słowa kluczowe: Inicjatywa Trójmorza, Europa Środkowo-Wschodnia, Europa Środkowa, Stany Zjednoczone, Niemcy, Unia Europejska

Powstanie Inicjatywy Trójmorza - zwanej też po prostu Trójmorzem - można próbować tłumaczyć na wiele sposobów, przez pryzmat różnych motywów działania i celów. Pomocnym narzędziem w wyjaśnianiu zachowań aktorów międzynarodowych są teorie stosunków międzynarodowych. Jedna z najważniejszych to obejmujący wiele nurtów realizm.

Teorie nie pozwalają oczywiście na precyzyjną i jednoznaczną interpretację wydarzeń czy procesów międzynarodowych. Dość powiedzieć, że nawet jeden fakt na gruncie jednej i tej samej teorii może być wyjaśniany na różne sposoby. Georg Sørensen i Robert Jackson, odnosząc się do debaty na temat rozszerzenia NATO, zauważyli na przykład, że wśród realistów na bazie tych samych kategorii teoretycznych formułowane były przeciwstawne argumentacje odnośnie do akcesji nowych państw: część z nich opowiadała się za ich przyjęciem, a część - przeciwko ${ }^{1}$. Mimo pewnych niedoskonałości rozważania teoretyczne należy uznać za potrzebne, ponieważ pomagają usystematyzować wiedzę, wyjaśnić zachodzące procesy i uchwycić pewne prawidłowości, a poza tym są pomocne w tworzeniu prognoz dotyczących dalszego rozwoju wydarzeń.

Należy tu zwrócić uwagę na krajową specyfikę i fakt, że „współcześni polscy realiści często piszą teksty abstrahujące od dzisiejszej sytuacji Polski”’2. $\mathrm{W}$ dużej mierze wynika to $\mathrm{z}$ obaw przed łatwą krytyką próby zastosowania teorii w analizie aktualnych wydarzeń. Mimo trudności warto jednak zmierzyć się z takim wyzwaniem. Niniejsza analiza nie wyczerpuje wszystkich wątków, które mogłyby zostać wykorzystane do wyjaśnienia powstania Inicjatywy

1 R. Jackson, G. Sørensen, Wprowadzenie do stosunków międzynarodowych. Teorie i kierunki badawcze, Wydawnictwo Uniwersytetu Jagiellońskiego, Kraków 2012, s. 88.

2 A. Wojciuk, J. Czaputowicz, Realizm w polskiej nauce o stosunkach międzynarodowych, [w:] Teoria realizmu w nauce o stosunkach międzynarodowych, red. J. Czaputowicz, E. Haliżak, PTSM, Rambler, Warszawa 2014, s. 217. 
Trójmorza w świetle teorii realizmu; ma jednak stanowić wstęp i zachętę do dalszych badań.

W teorii realizmu kluczowymi założeniami są pesymistyczna wizja natury ludzkiej oraz przekonanie o konfliktowym charakterze stosunków międzynarodowych, opartych na rywalizacji i groźbie wojny. Największe znaczenie przypisuje się w niej bezpieczeństwu państwa. Kluczowym pojęciem wyjaśniającym motywy działań państw jest natomiast kategoria potęgi, która stanowi podstawę definiowania interesu narodowego. W anarchicznym środowisku międzynarodowym, nad którym nie jest sprawowana nadrzędna władza, podstawowymi podmiotami są właśnie państwa, które podejmują racjonalne działania motywowane interesem narodowym. W analizie polityki zagranicznej decydujące znaczenie mają uwarunkowania międzynarodowe, w szczególności układ sił i miejsce państwa w strukturze porządku światowego ${ }^{3}$.

Wśród najważniejszych nurtów interesującej nas teorii należy wskazać realizm klasyczny, neorealizm i realizm neoklasyczny. Najczęściej wykorzystywana jest ona do badania niekooperatywnych zachowań państw, jak rywalizacja, realizowanie sprzecznych interesów, konflikty czy wojny. Także współpraca międzynarodowa rozumiana jest na gruncie realizmu w kontekście walki o interesy państw. Postrzegany w takim ujęciu proces integracji europejskiej głęboko modyfikuje środowisko, w którym odbywa się opisana przez Hansa Morgenthaua walka o potęgę. Unia Europejska przynosi zmianę uwarunkowań rywalizacji, ale nie neguje to podstawowego założenia realizmu klasycznego - o roli interesu narodowego jako uniwersalnej siły nadającej bieg stosunkom międzynarodowym ${ }^{4}$.

3 Szerzej na temat głównych założeń realizmu: J. Czaputowicz, Teorie stosunków międzynarodowych. Krytyka i systematyzacja, Wydawnictwo Naukowe PWN, Warszawa 2008; J.W. Legro, A. Moravcsik, Is anybody still a realist?, „International Security” 1999, vol. 24, No. 2, s. 5-55, dostępny w internecie [dostęp: 12 X 2018]: <https://www.princeton.edu/ amoravcs/library/anybody.pdf $>$; Teoria realizmu...; R. Jackson, G. Sørensen, Wprowadzenie..., s. 62; K. Narizny, On systemic paradigms and domestic politics. A critique of the newest realism, „International Security” 2017, vol. 42, issue 2, s. 155-190; S. Guzzini, Realizm w nauce o stosunkach międzynarodowych, Scholar, Warszawa 2017; J. Więcławski, Teoria realizmu Hansa J. Morgenthaua: koncepcje, krytyka i znaczenie dla wspótczesnych stosunków międzynarodowych, Instytut Nauk Politycznych Uniwersytetu Warmińsko-Mazurskiego, Olsztyn 2014; J. Snyder, One world, rival theories, „Foreign Policy” 2004, No. 145, s. 52-62.

4 J. Więcławski, Hans Morgenthau, realizm klasyczny i jego rekomendacje dla polskiej polityki zagranicznej, „Myśl Ekonomiczna i Polityczna” 2011, nr 3 (34), s. 121. 
Tabela 1. Porównanie realizmu klasycznego, neorealizmu i realizmu neoklasycznego (fragment tabeli opracowanej przez Jacka Czaputowicza)

\begin{tabular}{|l|l|l|l|}
\hline \multicolumn{1}{|c|}{$\times$} & Realizm klasyczny & $\begin{array}{c}\text { Realizm strukturalny } \\
\text { (neorealizm) }\end{array}$ & Realizm neoklasyczny \\
\hline $\begin{array}{l}\text { Zmienna } \\
\text { niezależna } \\
\text { interesy }\end{array}$ & $\begin{array}{l}\text { struktura systemu } \\
\text { międzynarodowego }\end{array}$ & $\begin{array}{l}\text { struktura systemu } \\
\text { międzynarodowego } \\
\text { w kontekście czynników } \\
\text { wewnątrzpaństwowych }\end{array}$ \\
\hline $\begin{array}{l}\text { Zmienna } \\
\text { zależna }\end{array}$ & $\begin{array}{l}\text { polityka zagraniczna } \\
\text { państw }\end{array}$ & $\begin{array}{l}\text { rezultaty na scenie } \\
\text { międzynarodowej } \\
\text { polityka zagraniczna } \\
\text { pantw }\end{array}$ \\
\hline Cel państw & $\begin{array}{l}\text { maksymalizacja } \\
\text { potęgi }\end{array}$ & $\begin{array}{l}\text { maksymalizacja } \\
\text { bezpieczeństwa }\end{array}$ & maksymalizacja wpływu \\
\hline Potęga & kontrola nad innymi & $\begin{array}{l}\text { suma zasobów (brak } \\
\text { i nadmiar może być } \\
\text { szkodliwy) }\end{array}$ & $\begin{array}{l}\text { funkcja czynników } \\
\text { materialnych } \\
\text { i niematerialnych }\end{array}$ \\
\hline $\begin{array}{l}\text { Sposób } \\
\text { realizacji celu }\end{array}$ & hegemonia & $\begin{array}{l}\text { równowaga sił } \\
\text { utrzymanie } \text { status quo } \\
\text { lub rewizjonizm }\end{array}$ \\
\hline Metodologia & $\begin{array}{l}\text { podejście } \\
\text { historyczne, } \\
\text { rozważania }\end{array}$ & $\begin{array}{l}\text { testowanie hipotez } \\
\text { za pomocą metod } \\
\text { ilościowych } \\
\text { i jakościowych }\end{array}$ & $\begin{array}{l}\text { metody jakościowe, } \\
\text { zwłaszcza analiza } \\
\text { przypadku i śledzenie } \\
\text { procesu }\end{array}$ \\
\hline
\end{tabular}

Źródło: J. Czaputowicz, Mapa współczesnego realizmu: realizm klasyczny, neorealizm, realizm neoklasyczny, [w:] Teoria realizmu w nauce o stosunkach międzynarodowych, red. J. Czaputowicz, E. Haliżak, PTSM, Rambler, Warszawa 2014, dostępny w internecie [dostęp: 12 X 2018]: <http://ptsm.edu.pl/wp-content/uploads/publikacje/teoria-realizmu-wnauce-o-stosunkach-miedzynarodowych/J.Czaputowicz.pdf $>$

Inicjatywę Trójmorza w świetle teorii realizmu można uznać za przykład współpracy międzynarodowej wynikającej z silnego dążenia do maksymalnego zaspokojenia interesów tworzących ją państw, które ze sobą rywalizują. Zasadniczo motywy zawiązywania współpracy tłumaczone są dwojako 5 .

Po pierwsze, współpraca następuje wtedy, gdy państwa połączy ograniczony interes wspólny, a jednocześnie szanują one wzajemnie swoje interesy narodowe, oraz gdy potencjalne korzyści przewyższają straty spowodowane częściowym ograniczeniem suwerenności. We współpracy liczą się przede wszystkim zyski relatywne, nie absolutne. Ważny jest wpływ na zmianę układu sił na scenie międzynarodowej, co oznacza, że „sprawujący władzę, oceniając możliwości współpracy gospodarczej, nie rozważają, czy dane państwo odniesie z niej w ogóle korzyści, lecz starają się stwierdzić, czy zyskają

5 P.J. Borkowski, Polityczne teorie integracji międzynarodowej, Difin, Warszawa 2007, s. 38. 


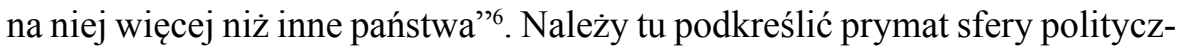
nej nad gospodarczą, gdyż z powodów politycznych państwa mogą się wycofać nawet $\mathrm{z}$ bardzo korzystnych projektów ekonomicznych.

Po drugie, do współpracy dochodzi, gdy rozkład potęgi w danej grupie powoduje pojawienie się hegemona, który może realizować partykularne interesy narodowe dzięki narzuceniu innym czy też przekonaniu ich, że są to interesy wspólne. Może być to współpraca skuteczna, ale będzie pochodną interesów dominującego państwa.

\section{Czym jest Inicjatywa Trójmorza}

Wiele wydarzeń zachodzących na początku drugiej dekady XXI w. wpisywało się w pesymistyczną wizję świata hobbesowskiego. Należy wśród nich podkreślić ekspansjonistyczną politykę Rosji, która w 2014 r. dokonała aneksji Krymu i rozpoczęła wojnę z Ukrainą. Poczucie bezpieczeństwa, jakie zapanowało w Europie Środkowo-Wschodniej po rozszerzeniu UE i NATO, ustępowało obawom związanym z wyłaniającym się nowym porządkiem. Stanowiący filar bezpieczeństwa państw tego regionu system euroatlantycki stanął przed poważnymi wyzwaniami.

W tych okolicznościach doszło do ożywienia współpracy regionalnej. W styczniu 2015 r. Austria, Czechy i Słowacja przyjęły deklarację sławkowską, co dało początek Trójkątowi Sławkowskiemu? Swą aktywność zwiększyła Grupa Wyszehradzka, sprzeciwiająca się zmianom unijnej polityki migracyjnej. W listopadzie 2015 r. z inicjatywy prezydentów Polski i Rumunii powołano tzw. dziewiątkę bukaresztańską (B9), czyli format służący zacieśnieniu relacji pomiędzy państwami wschodniej flanki NATO: Bułgarią, Czechami, Estonią, Litwą, Łotwą, Polską, Rumunią, Słowacją i Węgrami.

W tym samym roku pojawił się pomysł Inicjatywy Trójmorza. Jest to stworzona dzięki staraniom prezydentów Polski i Chorwacji, Andrzeja Dudy i Kolindy Grabar-Kitarović, forma współpracy w Europie Środkowo-Wschodniej ${ }^{8}$ obejmująca Austrię, Bułgarię, Chorwację, Czechy, Estonię,

$6 \quad$ A. Wróbel, Polityka handlowa w świetle założeń realizmu, [w:] Teoria realizmu..., s. 149.

7 D. Kałan, Trójkąt sławkowski: konkurencja dla Wyszehradu?, Polski Instytut Spraw Międzynarodowych, 16 II 2015 (Biuletyn PISM, 18 (1255)), dostępny w internecie [dostęp: 12 X 2018]: <www.pism.pl/files/?id_plik=19250>.

8 W deklaracji z Dubrownika występuje termin Europa Środkowa $i$ Wschodnia. W literaturze naukowej nie ma w tej kwestii jednolitości i w odniesieniu do obszaru państw Trójmorza używane są różne określenia, np. Europa Środkowo-Wschodnia, Europa Środkowa. 
Litwę, Łotwę, Polskę, Rumunię, Słowację, Słowenię i Węgry. Formalnie powołano ją 25 sierpnia 2016 r. poprzez przyjęcie Wspólnej deklaracji w sprawie Inicjatywy Trójmorza na I Szczycie Inicjatywy Trójmorza w Dubrowniku?. W świetle tego dokumentu, a także kolejnych deklaracji z Warszawy (6-7 lipca 2017 r. $)^{10}$ i Bukaresztu (17-18 września 2018 r.) ${ }^{11}$ Trójmorze to ugrupowanie wewnątrzunijne, skupiające się na rozwoju współpracy gospodarczej, zwłaszcza w sferze infrastruktury transportowej, energetycznej i komunikacji cyfrowej. Ma ono służyć rozwojowi państw leżących między Bałtykiem, Adriatykiem i Morzem Czarnym, a równocześnie wzmocnić spójność UE. Inicjatywa Trójmorza nie obejmuje współpracy militarnej ani bezpieczeństwa, z wyjątkiem bezpieczeństwa energetycznego. W deklaracji z Bukaresztu określono ją jako „nieformalną platformę prezydencką mającą wspierać pragmatyczną współpracę między jej państwami członkowskimi w oparciu o ich członkostwo w UE"12.

Kluczowe znaczenie dla funkcjonowania Inicjatywy Trójmorza mają doroczne spotkania prezydentów, które wzmacniają jej wymiar polityczny. Od 2018 r. w tym samym czasie organizowane jest otwarte dla szerokiego grona podmiotów Forum Biznesowe. Inicjatywa Trójmorza nie jest organizacją międzynarodową, co oznacza, że nie ma umowy założycielskiej ani statutu, który definiowałby jej cele i zadania. Opiera się na formule luźnej współpracy,

9 Wspólna deklaracja $w$ sprawie Inicjatywy Trójmorza, „Prezydent” [online], 25 VIII 2016 [dostęp: 12 X 2018], dostępny w internecie: <www.prezydent.pl/aktualnosci/wizyty-zagraniczne/art, 105, wspolna-deklaracja-w-sprawie-inicjatywy-trojmorza.html>. Na temat Inicjatywy Trójmorza zob.: M. Sienkiewicz, Koncepcja Trójmorza w polityce zagranicznej Polski po 2015 r., „Dyplomacja i Bezpieczeństwo” 2016, nr 1; P. Kowal, Czwarte Międzymorze?, „Obóz” 2016, nr 54; M. Gniazdowski, Trójmorze - nowy instrument w polskiej polityce zagranicznej, „Polski Przegląd Dyplomatyczny” 2017, nr 4 (71); T. Stępniewski, Inicjatywa Trójmorza: uwarunkowania geopolityczne i nowy model regionalnej wspótpracy, „Studia Europejskie” 2018, nr 2 (86), s. 33-44; P. Żurawski vel Grajewski, A. Baeva Motusić, K. Redlowska, Adriatic-Baltic-Black Sea. Visions of cooperation, Instytut Studiów Wschodnich, Warszawa 2017, dostępny w internecie [dostęp: 12 X 2018]: <http://www.forum-ekonomiczne.pl/wp-content/uploads/2017/08/ Adriatyk-Ba\%C5\%82tyk-Morze-Czarne16x24_2017en_PDF.pdf>; K. Szczerski, Utopia europejska: kryzys integracji i polska inicjatywa naprawy, Biały Kruk, Kraków 2017, s. 187-207 (rozdział 7: Trójmorze: nowa rola i miejsce Europy Środkowej).

10 The Second Summit of the 3 Seas Initiative Joint Declaration, „3 Seas Initiative Summit” [online, dostęp: 12 X 2018], dostępny w internecie: <www.three-seas.eu/wp-content/ uploads/2018/06/WARSAW.pdf>.

11 Joint declaration of the Third Summit of the Three Seas Initiative (Bucharest, 17-18 September 2018), ,3 Seas Initiative Summit” [online, dostęp: 12 X 2018], dostępny w internecie: <www.three-seas.eu/wp-content/uploads/2018/09/BUCHAREST-SUMMIT-JOINT-DECLARATION.pdf $>$.

12 Tamże. 
która dobrze wpisuje się w realistyczną wizję stosunków międzynarodowych. Wobec braku struktur instytucjonalnych państwo, które zmieni swoje stanowisko odnośnie do jakiegoś projektu ekonomicznego (nawet takiego, który wydaje się bardzo korzystny), może się z niego z łatwością wycofać.

Krytycy podkreślają, że Inicjatywa Trójmorza jest przejawem dążenia Polski do wzmocnienia swej pozycji i stania się liderem Europy Środkowo-Wschodniej poprzez osłabienie więzi z Niemcami, za to pod patronatem USA. Entuzjaści zwracają natomiast uwagę, że cele Trójmorza służą wzmocnieniu UE, a nawet całej wspólnoty euroatlantyckiej. Wraz z zasadniczą zmianą polityki Niemiec i Komisji Europejskiej wobec tego projektu latem 2018 r. zmniejszyła się liczba ocen krytycznych.

\section{Trójmorze a interesy USA}

Z perspektywy realizmu dla zrozumienia motywów współpracy państw tworzących Inicjatywę Trójmorza istotne znaczenie ma aktywność mocarstw, w szczególności USA, Rosji i Niemiec. Stany Zjednoczone, rzecz jasna, nie są i nie będą członkiem tego nowego projektu, ale okazują mu duże zainteresowanie ${ }^{13}$. Zgodnie z założeniami realizmu neoklasycznego źródła tego zaangażowania można szukać w dążeniu do maksymalizacji wpływów. W rywalizacji na poziomie globalnym inicjatywa może być zatem narzędziem długofalowego umacniania pozycji USA w tej części świata. Europa Środkowo-Wschodnia to ważny obszar pod względem strategicznym, ponieważ z jednej strony sąsiaduje z Rosją, otwarcie podważającą porządek unipolarny i dążącą do budowy świata wielobiegunowego, a z drugiej - z Niemcami, które po zjednoczeniu w 1990 r. systematycznie umacniają swoją pozycję,

13 Gen. James L. Jones, były doradca ds. bezpieczeństwa narodowego Baracka Obamy, mówił w rozmowie z Jędrzejem Bieleckim: „W tym kontekście niezwykłe znacznie ma polsko-amerykańska inicjatywa Trójmorza. Jestem w nią zaangażowany od czterech lat. To wtedy Atlantic Council opracował dokument, w którym wskazywał, jak bardzo w Europie Środkowej brakuje połączeń północ-południe, nie tylko energetycznych, ale także transportowych czy telekomunikacyjnych. Ten region nie był po wojnie objęty Planem Marshalla, a Związek Radziecki z wiadomych przyczyn rozwijał tu wyłącznie połączenia Wschód-Zachód. Ale dziś ten apel Atlantic Council przybiera realną formę 48 projektów z udziałem 12 krajów i amerykańskich funduszy inwestycyjnych. To jest teraz jeden z najważniejszych projektów geostrategicznych realizowanych na świecie! Nawet Niemcy chcą się do niego przyłączyć. To pokazuje, jak bardzo Ameryka wciąż jest zaangażowana w Europie”. Polska jest pierwsza linia obrony NATO, „Rzeczpospolita" [online], 10 XI 2018 [dostęp: 21 XI 2018], dostępny w internecie: $<$ http://archiwum. rp.pl/artykul/1389928-Polska-jest-pierwsza-linia-obrony-NATO.html>. 
ochładzając przy tym relacje z USA. Równocześnie relatywna przewaga militarna i gospodarcza Stanów Zjednoczonych nad innymi państwami maleje, co przekłada się na osłabienie ich pozycji jako supermocarstwa.

Odwołując się do teorii cykli hegemonicznych, która bazuje na założeniach realizmu, można dostrzec zjawiska wpisujące się w fazę delegitymizowania pozycji Stanów Zjednoczonych ${ }^{14}$. W grze o zmianę porządku światowego $\mathrm{z}$ jednobiegunowego na wielobiegunowy potencjalni rywale hegemona starają się z jednej strony czerpać korzyści z wciąż istniejącego układu, a z drugiej - podważać go. Żaden z krajów Europy Środkowo-Wschodniej nie jest potencjalnym rywalem USA ani nie aspiruje do roli mocarstwa światowego, co z perspektywy Waszyngtonu zwiększa atrakcyjność tego regionu. Rosja, Chiny, Turcja, ale również Niemcy podejmują natomiast liczne działania podważające pozycję USA, i to na wielu płaszczyznach - od próby delegitymizowania ich na poziomie retoryki (hegemon powinien być uznany za tak niekompetentnego i niebezpiecznego, aby pozbawienie go władzy wydawało się koniecznością), przez strategię oporu (np. głosowanie przeciw niemu w organizacjach międzynarodowych i prowokowanie rozłamów dyplomatycznych $)^{15}$.

Rozwój bloku państw położonych między Bałtykiem, Adriatykiem i Morzem Czarnym może pomóc ograniczyć tam wpływy m.in. Rosji i Niemiec, co leży także w interesie Stanów Zjednoczonych. Warto zwrócić uwagę, że po 2016 r. zawężono polityczną część formuły szczytów Trójmorza do państw UE i USA, w związku z czym zaproszenia na kolejne spotkanie nie wysłano do władz Chin ani Turcji. Zwiększyła się za to rola USA, o czym świadczył przyjazd prezydenta Donalda Trumpa do Warszawy w 2017 r. Rok później w Bukareszcie pojawił się sekretarz ds. energii Rick Perry ${ }^{16}$, a prezydent Trump

14 Jest to nawiązanie do teorii cykli hegemonicznych George'a Modelskiego. Zob. także R.L. Schweller, X. Pu, After unipolarity China's visions of international order in an era of U.S. decline, „International Security” 2011, vol. 36, No. 1, s. 41-72.

15 Przykładem może być sytuacja, gdy Niemcy ostro krytykowały wojnę USA w Iraku w 2003 r., a w 2011 r. w głosowaniu nad rezolucją nr 1973 w sprawie Libii na forum Rady Bezpieczeństwa wstrzymały się od głosu, podobnie jak Rosja, Chiny, Indie i Brazylia. Rezolucja została przyjęta 17 III 2012 r. Tekst dokumentu: Security council approves 'no-fly zone' over Libya, authorizing 'all necessary measures' to protect civilians, by vote of 10 in favour with 5 abstentions, „United Nations” [online], 17 III 2011 [dostęp: 12 X 2018], dostępny w internecie: <http://www.un.org/News/Press/docs/2011/sc10200. doc.htm>. Pisałam o tym w artykule: A. Orzelska-Stączek, Bezpieczeństwo Europy Środkowo-Wschodniej w perspektywie ładu globalnego ze szczególnym uwzględnieniem roli Polski, [w:] System euroatlantycki w wielobiegunowym tadzie międzynarodowym, red. J. Fiszer, Instytut Studiów Politycznych PAN, Warszawa 2013, s. 116-118.

16 Tekst wystąpienia: U.S. Secretary of Energy Rick Perry at the Three Seas Initiative Business Forum, „U.S. Embassy in Romania” [online], 20 IX 2018 [dostęp: 
zapewniał w liście do uczestników szczytu, że USA będą w dalszym ciągu silnie wspierać Inicjatywę Trójmorza. W deklaracji z Bukaresztu za trzy fundamentalne filary i cele uznano: wzmocnienie rozwoju gospodarczego, zwiększenie spójności UE oraz wzbogacenie więzi transatlantyckich, co było nowym elementem. Ponadto zapisano w niej, że ,gospodarcza obecność Stanów Zjednoczonych w regionie Trójmorza może przyczynić się do umocnienia więzi transatlantyckich i stać się dodatkowym katalizatorem dla wzmocnionego partnerstwa transatlantyckiego" ${ }^{17}$. Prezydent Andrzej Duda mówil, że „Trójmorze jest dla Ameryki strategicznym narzędziem budowania relacji z Europą Środkową"18. Ambitna koncepcja, by grupa ta służyła jako narzędzie budowania z USA strategicznego pomostu spajającego wspólnotę euroatlantycką, na razie wydaje się mało realna, ale stanowi punkt do rozważań. Prosto z Bukaresztu prezydent Polski udał się z oficjalną wizytą do Stanów Zjednoczonych. Chodziło o pokazanie, że jedzie tam jako emisariusz ze szczytu, a obie wizyty łączy koncepcja budowy silnego regionu Trójmorza ${ }^{19}$. Jednym z tematów rozmów prezydentów Andrzeja Dudy i Donalda Trumpa była możliwość wprowadzenia amerykańskich sankcji na konsorcjum budujące Nord Stream 2, co krytycznie przyjęli Niemcy ${ }^{20}$.

W realizmie potęga nie jest pojęciem statycznym, tzn. nie obejmuje jedynie aktualnych zasobów państwa. Pisał już o tym Hans Morgenthau, czołowa postać realizmu klasycznego: „Ze wszystkich błędów, jakie państwa mogą popełnić, oceniając potęgę [...], trzy występują niezwykle często. [...] Pierwszy błąd polega na zignorowaniu relatywności potęgi i dokonaniu absolutyzacji potęgi

12 X 2018], dostępny w internecie: <https://ro.usembassy.gov/secretary-of-energy-rick-perry-at-the-three-seas-initiative-business-forum/>.

17 Joint Declaration... O szczycie w Bukareszcie zob. B. Wiśniewski, Szczyt Inicjatywy Trójmorza w Bukareszcie - wizja nabiera kształtu, „Komentarz PISM” 2018, nr 64.

18 Wystapienie Prezydenta podczas Forum Biznesowego Trójmorza, „Prezydent” [online], 17 IX 2018 [dostęp: 12 X 2018], dostępny w internecie: <www.prezydent.pl/aktualnosci/wypowiedzi-prezydenta-rp/wystapienia/art,523, wystapienie-prezydenta-podczasforum-biznesowego-trojmorza.html $>$.

19 Minister Szczerski: Polska chce być silnym partnerem euroatlantyckiej wspólnoty, „Prezydent" [online], 17 IX 2018 [dostęp: 12 X 2018], dostępny w internecie: <www.prezydent.pl/kancelaria/aktywnosc-ministrow/art,1358, minister-szczerski-polska-chce-byc-silnym-podmiotem-euroatlantyckiej-wspolnoty.html>.

20 Minister ds. europejskich Niemiec Michael Roth powiedział w wywiadzie z Jędrzejem Bieleckim: „Muszę wyrazić zdziwienie, że europejski kraj partnerski ma zamiar zwrócić się do państwa trzeciego z postulatem wprowadzenia sankcji wobec europejskich przedsiębiorstw i osób indywidualnych $\mathrm{z}$ powodu ich zaangażowania $\mathrm{w}$ przedsięwzięcie infrastrukturalne, które jest realizowane zgodnie $\mathrm{z}$ istniejącymi europejskimi ramami prawnymi i wzmacnia bezpieczeństwo energetyczne Europy w zakresie dostaw gazu ziemnego". Niemcy o sporze UE z Polską: Chodzi o wolność, „,Rzeczpospolita”, 19 IX 2018. 
konkretnego państwa; drugi polega na założeniu trwałości czynnika, który w przeszłości odgrywał decydującą rolę, i przeoczeniu dynamicznej zmiany, jakiej podlega większość czynników potęgi; trzeci zaś polega na przypisywaniu decydującego znaczenia jednemu z czynników przy pominięciu pozostałych" ${ }^{21}$. Marcin Kaczmarski, analizując realizm neoklasyczny, stwierdził, że w podejściu dynamicznym pojęcie potęgi skupia się na interakcjach: ,[...] potęga państwa jest określana przez jego możliwości, chęć (oraz percepcję tej chęci) do jej użycia oraz jego kontrolę (wpływ na inne państwa). Potęgę tworzy wówczas zdolność wpływania na inne państwa"22. Współpraca w ramach Trójmorza może być zatem przedstawiana jako podejmowana przez Amerykanów (najsilniejszy kraj kojarzony z tą inicjatywą) próba zwiększenia zdolności wpływania na inne państwa.

Współpraca gospodarcza dopuszczana jest w realizmie pod warunkiem, że nie prowadzi do relatywnego zwiększenia siły innego państwa, które przecież w przyszłości z partnera może stać się przeciwnikiem. Nie może być ona czynnikiem niekorzystnej zmiany układu sił. Współpraca z krajami Europy Środkowo-Wschodniej nie niesie dla USA takiego ryzyka, jest to bowiem region silnie rozdrobniony politycznie, obejmujący kraje małe i średnie, które nie mają własnych znaczących złóż gazu, a wykorzystują duże jego ilości. Amerykanie intensywnie szukają odbiorców gazu skroplonego (LNG), więc daje im to szansę na zdobycie nowych rynków i zablokowanie wpływów potencjalnych konkurentów. W 2016 r. analitycy ostrzegali, że połowie amerykańskich projektów LNG grozi zamknięcie w ciągu pięciu lat, jeśli nie znajdą nowych kontrahentów i nie wyeliminują z Europy katarskiej i rosyjskiej konkurencji ${ }^{23}$. Realizacja wielkich projektów infrastrukturalnych - jak rozbudowa terminala LNG w Świnoujściu, budowa terminala na chorwackiej wyspie Krk, budowa połączeń transportowych północ-południe, gazociągów i ropociągów - ułatwiłaby przesyłanie surowców, wpływając też na poziom bezpieczeństwa energetycznego Europy Środkowo-Wschodniej. Z punktu widzenia Rosji jest to działanie wymierzone w jej żywotne interesy. Komplikowałoby też plany Niemiec, które zamierzają stać się środkowoeuropejskim hubem

21 H. Morgenthau, Polityka między narodami. Walka o potęgę i pokój, Difin, Warszawa 2010, s. 177.

22 M. Kaczmarski, Realizm neoklasyczny, [w:] Teorie i podejścia badawcze w nauce o stosunkach międzynarodowych, red. R. Zięba, S. Bieleń, J. Zając, Wydział Dziennikarstwa i Nauk Politycznych UW, Warszawa 2015, s. 18.

23 J. Clemente, Six threats for the U.S. liquefied natural gas business, „Forbes” [online], $15 \mathrm{~V}$ 2015 [dostęp: 12 X 2018], dostępny w internecie: <www.forbes.com/sites/judeclemente/ 2016/05/15/six-threats-for-the-u-s-liquefied-natural-gas-business/\#448f00413alb>. 
gazowym. W przypadku USA potencjalne korzyści z takiej wymiany handlowej mogłyby natomiast prowadzić do umocnienia ich potęgi gospodarczejej. $\mathrm{W}$ realizmie zaliczane do hard power czynniki materialne stanowią centralną kategorię wśród wyznaczników potęgi. Współcześnie potencjał gospodarczy państwa jako element potęgi zyskuje na znaczeniu.

\section{Trójmorze a państwa Europy Środkowo-Wschodniej}

W teorii realizmu silnie podkreślane jest bezpieczeństwo. W sztywnej hierarchii celów przetrwanie i wzmacnianie bezpieczeństwa stają się celami nadrzędnymi. Wzmocnienie bezpieczeństwa ma charakter relatywny, czyli oceniane jest zawsze w porównaniu do możliwości innych państw. Kluczem do wyjaśnienia ich działań na arenie międzynarodowej są aktualne uwarunkowania - układ sił.

W realizmie akcentuje się możliwość wybuchu konfliktu i groźbę wojny w stosunkach międzynarodowych. Dla Europy Środkowo-Wschodniej istotne znaczenie mają rosnąca niepewność co do zachowania innych państw (zwłaszcza Rosji) oraz słabość UE w wymiarze bezpieczeństwa i obrony, obciążonej dodatkowo konsekwencjami kryzysu migracyjnego i brexitu. Inicjatywa Trójmorza koncentruje się wprawdzie na projektach infrastrukturalnych, ale ma też duże znaczenie polityczne, zwłaszcza dla zwiększania znaczenia Europy Środkowo-Wschodniej w UE, rozwijania współpracy z USA oraz podnoszenia bezpieczeństwa energetycznego. Do jej powstania doszło po aneksji Krymu przez Federację Rosyjską w 2014 r., która zburzyła dotychczasową architekturę bezpieczeństwa w regionie. Obawy niektórych krajów tego obszaru, a w szczególności Polski, budzi też zacieśnienie rosyjsko-niemieckiej współpracy w sferze energetyki. W 2011 r. oddano do użytku pierwszą nitkę rurociągu Nord Stream, a prace nad jego rozbudową przyspieszyły w 2015 r. W maju 2018 r. firma Nord Stream 2 oficjalnie ogłosiła w Lubminie w Meklemburgii-Pomorzu Przednim rozpoczęcie budowy drugiej nitki rurociągu, która ma być gotowa do końca 2019 r. Na szczycie Inicjatywy Trójmorza w Bukareszcie premier Mateusz Morawiecki otwarcie wyraził niepokój i brak zgody na budowę tego gazociągu, ale niemieckie władze utrzymują, że to „przedsięwzięcie infrastrukturalne, które jest realizowane zgodnie $\mathrm{z}$ istniejącymi europejskimi ramami prawnymi i wzmacnia bezpieczeństwo energetyczne Europy w zakresie dostaw

24 Problematyka ta poruszona została w monografii: P. Kowal, A. Orzelska-Stączek, Inicjatywa Trójmorza. Geneza, cele i funkcjonowanie, Instytut Studiów Politycznych PAN, Warszawa 2019. 
gazu ziemnego"25. Bezpieczeństwo energetyczne należy do głównych obszarów zainteresowania Inicjatywy Trójmorza, a jeden z jego flagowych projektów to korytarz gazowy łączący terminal LNG w Świnoujściu i Gazociąg Bałtycki (Baltic Pipe) z terminalem Adria LNG na wyspie Krk.

Państwa Europy Środkowo-Wschodniej różnią się co do oceny zagrożeń i interesów w polityce wobec Rosji. Część z nich - zwłaszcza Litwa, Łotwa, Estonia, Polska i Rumunia - dostrzega w działaniach Kremla zagrożenie. Inne, jak Czechy, Słowacja, Węgry i Słowenia, akcentują pozytywne aspekty relacji gospodarczo-energetycznych z Moskwą, ale nie wyłamują się ze wspólnego europejskiego frontu sankcji wobec Rosji i nie przeciwstawiają się wzmocnieniu wschodniej flanki NATO ${ }^{26}$. Mimo pewnych różnic obawy związane z potencjalnymi zagrożeniami skłaniają państwa Europy Środkowo-Wschodniej do zacieśnienia więzi ze Stanami Zjednoczonymi. Ich głównym celem nie jest dążenie do maksymalizacji potęgi, jak w przypadku USA, lecz maksymalizacja bezpieczeństwa, co akcentuje neorealizm.

W takim ujęciu Trójmorze jawi się jako próba umacniania transatlantyckiej wizji Europy opartej na silnym zaangażowaniu Stanów Zjednoczonych na Starym Kontynencie. Poza Austrią wszystkie kraje Trójmorza należą do Sojuszu Północnoatlantyckiego, który jest filarem bezpieczeństwa wspólnoty euroatlantyckiej. Dysproporcja między wydatkami obronnymi USA i kolejnych państw wskazanych w rankingu SIPRI zmniejsza się co prawda relatywnie, ale wciąż pozostaje ogromna. Z perspektywy państw Europy Środkowo-Wschodniej nie ma obecnie alternatywy dla USA jako głównego gwaranta bezpieczeństwa i najsilniejszego sojusznika w ramach NATO.

\section{Trójmorze jako próba równoważenia rosnących potęg}

Odwołując się znów do neorealizmu, należy wskazać, że wspierane przez Stany Zjednoczone Trójmorze postrzegane bywa jako próba równoważenia rosnącej potęgi Niemiec. Na poziomie regionalnym ograniczałoby ono wpływy Berlina w Europie Środkowo-Wschodniej, na europejskim byłoby próbą stworzenia dla niego przeciwwagi w UE, a w wymiarze globalnym stanowiłoby reakcję na procesy zachodzące na poziomie międzynarodowym, czyli słabnącą pozycję USA oraz zacieśnianie relacji rosyjsko-niemieckich.

25 Niemcy o sporze...

26 P. Ukielski, Mapa Trójmorza. Przegląd punktów wspólnych i rozbieżności $w$ polityce 12 państw regionu, Centrum Analiz Klubu Jagiellońskiego 2016 (Raport, 3/2016). 


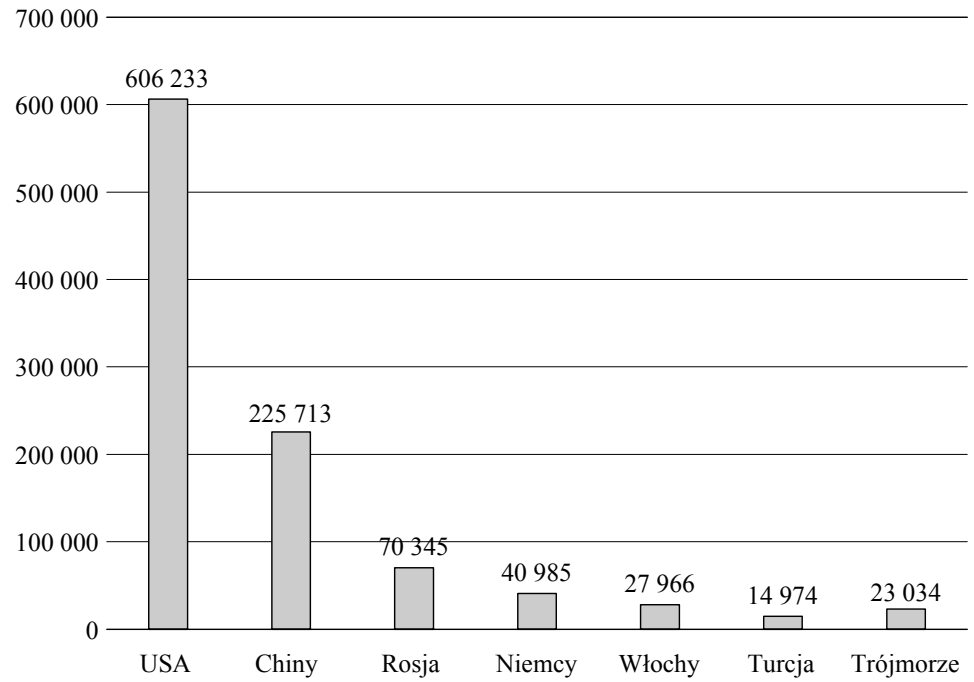

\section{Wykres 1. Wydatki militarne wybranych państw oraz grupy Trójmorza w 2016 r. (constant prices w mln dol.)}

Żródło: oprac. własne na podstawie danych SIPRI: Military expenditure by country, in constant (2015) US\$ m., „Stockholm International Peace Research Insitute”

[online, dostęp: 12 X 2018], dostępny w internecie:

$<$ www.sipri.org/sites/default/files/Milex-constant-2015-USD.pdf $>$

12000

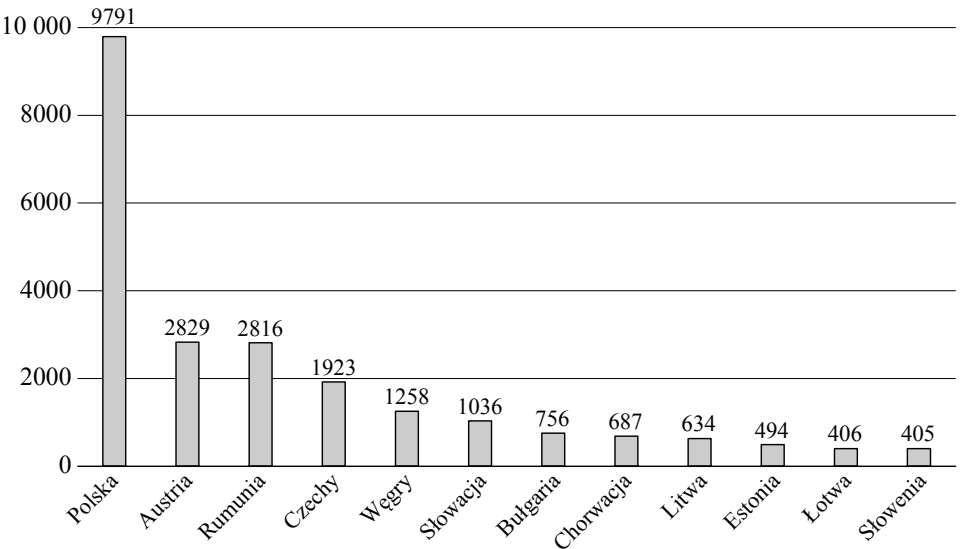

Wykres 2. Wydatki militarne państw Trójmorza w 2016 r. (constant prices $\mathrm{w}$ mln dol.)

Źródło: oprac. własne na podstawie danych SIPRI: Military expenditure by country, in constant (2015) US\$ m., „Stockholm International Peace Research Insitute”

[online, dostęp: 12 X 2018], dostępny w internecie:

$<$ www.sipri.org/sites/default/files/Milex-constant-2015-USD.pdf $>$ 
Równoważenie potęgi Niemiec jest tematem wielu prac dotyczących integracji europejskiej. Po zjednoczeniu NRD i RFN w centrum Europy powstało państwo znacznie potężniejsze od innych, co zmieniło dotychczasowy układ sił. Wśród naukowców pojawiły się opinie, że odradzająca się niemiecka potęga zmusiła pozostałych członków UE do podjęcia działań mających na celu jej ograniczenie i kontrolowanie, czego skutkiem było wzmocnienie struktur europejskich ${ }^{27}$. Silne związanie Niemiec siecią unijnych struktur przedstawiane było przez realistów jako jedna $\mathrm{z}$ odpowiedzi na zachwianie istniejącej równowagi sił. Tego rodzaju rozwiązanie nie może mieć jednak zastosowania w przypadku Trójmorza z tej prostej przyczyny, że Niemcy pozostają i w najbliższym czasie pozostaną poza tą grupą państw.

Z perspektywy Berlina początkowo projekt ten wyglądał na próbę utworzenia bloku konkurencyjnego wobec starej Europy, mającego zburzyć dotychczasowy układ sił w UE, co byłoby niekorzystne dla Niemiec. Ze względu na nikły potencjał nie stał się on jednak przedmiotem poważnej debaty w tym $\mathrm{kraju}^{28}$. Interesujący zwrot nastąpił latem 2018 r., gdy RFN wyraziła chęć dołączenia do Inicjatywy Trójmorza. Postulat ten poparł przewodniczący Komisji Europejskiej Jean-Claude Juncker, który we wrześniu 2018 r. po raz pierwszy gościł na jej szczycie. Było to też pierwsze spotkanie w ramach tego formatu, w którym wziął udział przedstawiciel rządu niemieckiego - minister spraw zagranicznych Heiko Maas. Twierdził on, że Niemcy pasują do inicjatywy Trójmorza ze względów historycznych, politycznych, gospodarczych i geograficznych (położenie nad Bałtykiem). Podkreślał, że jego kraj jest głównym partnerem gospodarczym każdego z członków Trójmorza, a jego wschodnia część doświadczyła - podobnie jak one - procesów transformacyjnych ${ }^{29}$.

27 J.M. Grieco, State interests and institutional rule trajectories. A neorealist interpretation of the Maastricht treaty and European economic and monetary union, „Security Studies” 1996, vol. 5, s. 261-306. Artykuł ten przywołuje Paweł Janusz Borkowski: P.J. Borkowski, Polityczne teorie..., s. 42.

28 M. Dahl, Inicjatywa Trójmorza z perspektywy niemieckiej, „Studia Europejskie” 2018, nr 2 (86), s. 59-72. „Many German officials, including Chancellor Angela Merkel, reportedly believe that the $3 \mathrm{SI}$ is an attempt to divide the European Union and to balance against Germany and France within the EU". V. Rotaru, A. Umland, How Romania and Poland can strengthen NATO and the EU. Two new cooperation initiatives could improve regional security, „Foreign Affairs” [online], 10 XI 2017 [dostęp: 12 X 2018], dostępny w internecie: <www.foreignaffairs.com/articles/central-europe/2017-11-10/how-romania-and-poland-can-strengthen-nato-and-eu>.

29 Niemcy chca do Trójmorza. „,Nowa polityka wschodnia”, „Deutsche Welle” [online], 19 IX 2018 [dostęp: 12 X 2018], dostępny w internecie: <www.dw.com/pl/niemcy-chc\%C4\%85-do-tr\%C3\%B3jmorza-nowa-polityka-wschodnia/a-45549145>. 
Zaangażowanie Niemiec wzmacniałoby szanse rozwoju współpracy Trójmorza z instytucjami UE, co jest zgodne z interesami państw Europy Środkowo-Wschodniej. Obawy budzi natomiast zagrożenie, że potężny sąsiad zdominuje tę inicjatywę i dzięki narzuceniu innym preferowanych rozwiązań czy też przekonaniu ich, że chodzi o korzyści wspólne, realizował będzie partykularne interesy narodowe. Choć mogłaby to być współpraca efektywna, to jednak stanowiłaby pochodną interesów Niemiec, które coraz wyraźniej promują postatlantycką wizję Europy, a jednocześnie śmiało angażują się przedsięwzięcia kolidujące z interesami mniejszych państw Europy Środkowo-Wschodniej, np. Nord Stream. Ostatecznie Polska i pozostałe państwa Inicjatywy Trójmorza zgodziły się jedynie na to, by Niemcy były w tym projekcie państwem partnerskim ${ }^{30}$.

Na poziomie globalnym Trójmorze może być traktowane jako próba równoważenia nie tylko potęgi Niemiec, ale też Rosji i Turcji, a nawet Chin. Historia pokazuje, że przez stulecia Europa Środkowo-Wschodnia znajdowała się pod władzą Rosji, Prus (Niemiec), Habsburgów i Turcji, a próby przeciwstawienia się dominacji tych mocarstw kończyły się niepowodzeniem. Obecnie Niemcy i Rosja intensywnie starają się umocnić tu swoją obecność ze względu na swe interesy strategiczne i ekonomiczne. Powstanie wspieranej przez USA silnej struktury środkowoeuropejskiej mogłoby kolidować z tymi planami.

Osobną kwestią jest zwiększona aktywność Chin w Europie Środkowo-Wschodniej, przejawiająca się m.in. w powstałym z inicjatywy Pekinu formacie 16+1, którego szczyty organizowane są rokrocznie od spotkania w Warszawie w 2012 r. ${ }^{31}$ Biorą w nich udział wszystkie kraje Trójmorza $\mathrm{z}$ wyjątkiem Austrii, a także pozaunijne państwa bałkańskie: Albania, Bośnia i Hercegowina, Czarnogóra, Macedonia oraz Serbia. ChRL staje się dla USA jednym z głównych rywali w wymiarze globalnym, a interesy obu państw w Europie Środkowo-Wschodniej wyraźnie ze sobą kolidują. Donald Trump zaliczył Chiny i Rosję do głównych mocarstw rewizjonistycznych, które stanowią wyzwanie dla Ameryki ${ }^{32}$.

30 Polska poparła wniosek Niemiec o status państwa partnerskiego Inicjatywy Trójmorza, „Prezydent” [online], 28 VIII 2018 [dostęp: 12 X 2018], dostępny w internecie: <www. prezydent.pl/kancelaria/aktywnosc-ministrow/art,1311,polska-poparla-wniosek-niemiec -o-status-panstwa-partnerskiego-inicjatywy-trojmorza.html>.

31 „Cooperation between China and Central and Eastern European Countries” [online, dostęp: 12 X 2018], dostępny w internecie: <www.china-ceec.org/eng/>.

32 National Security Strategy of the United States of America. December 2017, „The White House" [online, dostęp: 12 X 2018], dostępny w internecie: <https://www.whitehouse. gov/wp-content/uploads/2017/12/NSS-Final-12-18-2017-0905.pdf $>$. 
Na tym tle warto zwrócić uwagę na delegacje, które brały udział w forum Inicjatywy Trójmorza w Dubrowniku w 2016 r. Zgodnie z programem obrady otwierali prezydenci Chorwacji i Polski - Kolinda Grabar-Kitarović oraz Andrzej Duda, a po nich głos zabrali kolejno gen. James L. Jones, jako przewodniczący Jones Group International i doradca prezydenta Baracka Obamy do spraw bezpieczeństwa, oraz Liu Haixing z ministerstwa spraw zagranicznych Chin, pełniący również funkcję sekretarza generalnego sekretariatu ds. współpracy ChRL z państwami Europy Środkowej i Wschodniej ${ }^{33}$. W dyskusjach panelowych uczestniczyli też m.in. wiceminister spraw zagranicznych Turcji Ahmet Yildiz oraz zastępca asystenta sekretarza stanu USA ds. Europy i Eurazji Hoyt Brian Yee. Udział wymienionych osób w obradach szczytu odczytywano jako sygnał dużego zainteresowania nową inicjatywą ze strony USA, Chin i Turcji. Po zawężeniu formuły spotkań na szczytach do prezydentów państw Trójmorza w kolejnych latach nie pojawiali się już na nich przedstawiciele Ankary ani Pekinu.

\section{Trójmorze jako czynnik integrujący czy dezintegrujący Unię Europejską?}

W odniesieniu do Unii Europejskiej Trójmorze może być postrzegane dwojako - jako czynnik integrujący bądź dezintegrujący wspólnotę.

Z perspektywy neorealizmu powołanie tego projektu można uznać za rozwiązanie służące wzmocnieniu całej UE w zmieniającym się porządku międzynarodowym. Trójmorze mogłoby bowiem stać się czynnikiem konsolidującym wspólnotę w skonfliktowanym świecie opartym na rywalizacji. To właśnie $\mathrm{w}$ dążeniu do rywalizacji na poziomie globalnym realizm upatruje główną siłę napędową integracji i wyjaśnienie procesów zachodzących w łonie UE. Trójmorze mogłoby zatem wesprzeć Wspólnotę w rywalizacji z innymi ośrodkami gospodarczymi i politycznymi: Chinami, Japonią, Rosją, Turcją, USA itd. Jeśli jednak celem Unii byłaby rywalizacja na scenie globalnej z USA, to Amerykanie nie mieliby interesu we wzmacnianiu jej poprzez wspieranie Inicjatywy Trójmorza.

33 Jego dokładny tytuł brzmiał: ,assistant Minister of Foreign Affairs of the People's Republic of China, Secretary-General of the Secretariat for Cooperation between China and Central and Eastern European Countries". Program forum zob. Dubrownik Forum 2016. „Strengthening Europe: connecting north and south”, „Ministarstvo vanjskih i europskih poslova" [online, dostęp: 12 X 2018], dostępny w internecie: <http://www.mvep.hr/files/ file/2016/1608222-dubrovnik-forum-draft-program.pdf $>$. 
Trudno też odpowiedzieć na pytanie, preferencje polityczne którego najsilniejszego państwa miałoby odzwierciedlać Trójmorze. Najpotężniejsze państwa UE, jakimi są Niemcy i Francja, początkowo dystansowały się od tej inicjatywy, a późniejsza próba włączenia się do niej przez Berlin wzbudziła obawy, że może on zdominować ten format, i na razie zakończyła się niepowodzeniem. Jeśli za najsilniejsze państwo w tej grupie uznamy Polskę, to w ślad za tym należy stwierdzić, że na tle Europy Środkowo-Wschodniej jej potencjał jest znaczący, ale wobec Niemiec, Francji, Turcji czy Rosji - już dużo mniejszy. Przy obecnym układzie sił Polska nie ma możliwości skłonienia kilkunastu państw regionu do współpracy, jeśli byłoby to wbrew interesom potęg.

Próba wyjaśnienia powstania Trójmorza jako czynnika integrującego UE może się zatem opierać tylko na podkreślaniu dążenia do integracji całej wspólnoty euroatlantyckiej, która jako całość byłaby zdolna lepiej rywalizować $\mathrm{z}$ innymi ośrodkami potęgi. Rozumowanie to nie wytrzymuje jednak próby w konfrontacji z obserwowanym w ostatnim czasie negatywnym trendem w relacjach Stanów Zjednoczonych z Unią Europejską, który przejawia się w rosnącej liczbie napięć w ich wzajemnych relacjach (o czym świadczą np. fiasko negocjacji w sprawie TTIP, niespodziewane wprowadzenie wysokich ceł na stal i aluminium przez USA w marcu 2018 r.), a także w bilateralnych stosunkach Waszyngtonu z Berlinem i Paryżem.

Powstanie Trójmorza można też jednak thumaczyć inaczej - jako czynnik dezintegrujący UE, albo raczej wzmacniający procesy dezintegracyjne dotykające słabnącą Wspólnotę, dzięki czemu ograniczona zostałaby jej zdolność do konkurowania z USA. Wpisują się w to opinie, że Trójmorze ma być konkurencją polityczną dla starej Unii Europejskiej, przeciwwagą dla Brukseli, Berlina i Paryża, a nawet krokiem do powołania alternatywnej, środkowoeuropejskiej struktury po rozpadzie UE. Byłby to krok ku zwiększeniu roli krajów Europy Środkowo-Wschodniej jako skonsolidowanego bloku, ale kosztem Unii. Realiści wieścili rychły schyłek procesu integracji już na początku lat dziewięćdziesiątych XX w., gdy zniknęło zagrożenie w postaci ZSRR ${ }^{34}$. Początkowo wydawało się, że do tego nie dojdzie, gdyż integracja dynamicznie się pogłębiała, ale już po kilkunastu latach UE znalazła się w głębokim kryzysie.

34 J.J. Mearsheimer, Back to the future: instability in Europe after the Cold War, „International Security" 1990, vol. 15, No. 1, s. 5-56, dostępny w internecie [dostęp: 12 X 2018]: $<$ http://mearsheimer.uchicago.edu/pdfs/A0017.pdf $>$. 
Problemom wewnętrznym Unii Europejskiej towarzyszy wzmocnienie roli państw narodowych. W realizmie klasycznym, państwocentrycznym, stosunki międzynarodowe opierają się na relacjach między suwerennymi państwami, które zachowują pełną kontrolę nad swoją ludnością, terytorium i zasobami wewnętrznymi. Trójmorze można więc postrzegać w tym rozumieniu jako krok ku odwracaniu się od modelu integracyjnego na rzecz współpracy międzyrządowej, kształtowanej przez tradycyjne kanały polityki zagranicznej. Wyjaśniałoby to, dlaczego kluczową rolę pełnią w tym formacie najwyżsi przedstawiciele państw, dlaczego nie przyjęto żadnego traktatu ani nie podjęto kroków ku instytucjonalizacji tej współpracy. Na dwóch pierwszych szczytach Trójmorza - w Dubrowniku i Warszawie - zabrakło wyższej rangi przedstawicieli $\mathrm{UE}^{35}$, z czym kontrastuje fakt, że Bruksela aktywnie angażuje się w liczne formy współpracy regionalnej, a Komisja Europejska jest nawet jednym z członków Rady Państw Morza Bałtyckiego.

Oficjalnie KE nie uważała Inicjatywy Trójmorza za problematyczną, ale w Brukseli postrzegano ją jako próbę zjednoczenia regionu przez Polskę, która pod swoim przywództwem dążyła do stworzenia w UE przeciwwagi dla niemiecko-francuskiej siły ${ }^{36}$. W 2018 r. stanowisko Komisji uległo zmianie; 18 września na szczycie w Bukareszcie przewodniczący Jean-Claude Juncker stwierdził: ,[...] straciliśmy okazję, by pozytywnie odpowiedzieć na zaproszenie od prezydent Chorwacji dwa lata temu i na zaproszenie od rządu polskiego rok temu. Ale jesteśmy tu dziś, bo uważamy, że to, co robicie, czego się podejmujecie, uzupełnia działania Unii Europejskiej, które stara się ona zrealizować" ${ }^{37}$.

35 Według programu forum ze strony UE udział wzięli jedynie Andrej Plenković, przewodniczący Chorwackiej Wspólnoty Demokratycznej i wiceprzewodniczacy Komitetu ds. Spraw Zagranicznych Parlamentu Europejskiego, oraz Georgette Lalis, główny doradca dyrektora generalnego ds. energii przy Komisji Europejskiej. Dubrownik Forum 2016...

36 J. Kuczkiewicz, La ,nouvelle Europe” se réunit à 12 pour recevoir chaleureusement Donald Trump, „Le Soir” [online], 5 VII 2017 [dostęp: 12 X 2018], dostępny w internecie: $<$ http://plus.lesoir.be/103076/article/2017-07-05/la-nouvelle-europe-se-reunit-12-pour-recevoir-chaleureusement-donald-trump $>$. Artykuł był szeroko komentowany. Zob. np. Belgijski dziennik o Trójmorzu: Polska próbuje zjednoczyć region, „TVN 24” [online], 5 VII 2017 [dostęp: 12 X 2018], dostępny w internecie: <www.tvn24.pl/wiadomosci-ze-swiata, 2/le-soir-o-trojmorzu-polska-probuje-zjednoczyc-region, 754456.html>; B. Zalewski, Strach to zły doradca dyplomatów od wizji Trójmorza, „RMF 24” [online], 6 VII 2017 [dostęp: 12 X 2018], dostępny w internecie: <www.rmf24.pl/fakty/swiat/ news-strach-to-zly-doradca-dyplomatow-od-wizji-trojmorza,nId,2413717>.

37 Discours du Président Jean-Claude Juncker au sommet de l'Initiative des Trois Mers, „European Commission” [online], 18 IX 2018 [dostęp: 12 X 2018], dostępny w internecie: $<$ http://europa.eu/rapid/press-release_SPEECH-18-5825_fr.htm>. Zob. też P. Kowal, A. Orzelska-Stączek, Inicjatywa Trójmorza... 
Doskonałe relacje Brukseli i Berlina oraz ich spójna polityka wobec Trójmorza kontrastowały z narastającymi problemami w stosunkach z instytucjami unijnymi, z jakimi borykały się zwłaszcza Polska i Węgry, względem których uruchomiono procedurę $\mathrm{z}$ art. 7 traktatu $\mathrm{z}$ Lizbony. Pogłębiało to wrażenie podziału UE na silniejsze kraje Europy Zachodniej oraz słabsze, ze środkowo-wschodniej części kontynentu. Pokonanie utrzymujących się podziałów w UE było jednym z głównych motywów powołania Inicjatywy Trójmorza.

\section{Trójmorze z perspektywy wybranych krajów Europy Środkowo-Wschodniej}

Po rozważaniach dotyczących znaczenia Inicjatywy Trójmorza na poziomie globalnym i regionalnym warto spojrzeć na ten projekt przez pryzmat interesów jego poszczególnych uczestników. Nie ma tu miejsca na omówienie wszystkich dwunastu państw, więc przedstawione zostaną Polska, jako największe państwo pod względem terytorium i populacji, a także zaliczana do małych państw Chorwacja.

Będąca nieformalnym liderem Trójmorza Polska musi określić cel swoich działań adekwatnie do zasobów. Innymi słowy, jak stwierdził Morgenthau, państwo „musi wybrać cele i metody swej polityki zagranicznej z uwzględnieniem potęgi, którą może wykorzystać dla osiągnięcia maksymalnego sukcesu. Państwo, które ustawia sobie próg zbyt nisko, rezygnując z polityki, jaka znajduje się w jego zasięgu, rezygnuje z przynależnego sobie stanowiska [...]. Państwo może mieć również zbyt wysokie aspiracje i prowadzić politykę, która wedle posiadanej potęgi nie ma szans powodzenia"38. Ponadto zauważył, że znalezienie równowagi między zasobami a prowadzoną polityką leży w rękach dyplomacji, bo ,ze wszystkich czynników składających się na potęgę narodu najważniejszym, choć niestabilnym, jest jakość dyplomacji”39.

Polska postrzegana jest jako kraj, który ma ambicje i potencjał, by odgrywać rolę lidera Trójmorza. Budowa dobrych relacji z państwami Europy Środkowo-Wschodniej wzmocniłaby jej prestiż, możliwości wpływania na inne kraje, a także pozycję w relacjach z Rosją i Niemcami. Równocześnie pojawiają się obawy, czy zaangażowanie w ten projekt nie pogorszy relacji Polski z innymi państwami, np. gdyby został on uznany za próbę narzucenia im polityki promującej interesy najsilniejszego w tym gronie, czyli właśnie Polski. Mogłoby tu chodzić np. o dążenie do zaostrzenia polityki innych krajów Europy

38 H. Morgenthau, Polityka.., s. 167.

39 Tamże, s. 163. 
Środkowo-Wschodniej wobec Rosji. Podobne obawy formułowane były zresztą już w okresie międzywojennym, co wpłynęło na zablokowanie możliwości dołączenia przez Polskę do ówczesnych form współpracy regionalnej.

Wziąwszy pod uwagę rozkład sił w Europie Środkowo-Wschodniej, trudno jednak przypisywać Polsce aspiracje i możliwości wykorzystania Trójmorza do realizacji jej interesów narodowych poprzez przekonanie innych, że są to interesy wspólne, czy narzucenie im własnej woli. Ewentualne obawy innych państw przed zbyt dużym wzmocnieniem pozycji Polski neutralizowane są z jednej strony zainteresowaniem USA Inicjatywą Trójmorza, a z drugiej - potencjałem innych państw Europy Środkowo-Wschodniej i aktywnością regionalnych mocarstw, jak również samej UE. Bez względu na realne cele i motywy Warszawy jej zaangażowanie w ten projekt wpłynie na zmianę pozycji Polski na arenie międzynarodowej w stopniu zależnym od skali sukcesu bądź fiaska całej koncepcji.

Większość podmiotów wchodzących w skład Trójmorza to państwa małe, jak np. Chorwacja. Teoria realizmu tłumaczy, że dzięki współpracy międzynarodowej i uczestnictwu w strukturach instytucjonalnych zyskują one więcej informacji o zachodzących tam procesach i mają większy wpływ na podejmowane decyzje. Dla małych i słabych państw współpraca z innymi podmiotami może być zarówno narzędziem zapewnienia sobie wpływu na procesy międzynarodowe, jak i środkiem ograniczającym potęgę państw silnych ${ }^{40}$. Chorwacja, która wraz z Polską zainicjowała Trójmorze, zwiększyła dzięki temu swój prestiż i wzmocniła swoją pozycję na scenie międzynarodowej.

\section{Podsumowanie}

Teoria realizmu dobrze wyjaśnia motywy rywalizacji i konfliktów, koncentrując się na aspektach bezpieczeństwa i potęgi oraz akcentując rolę interesów narodowych. Wyjaśnianie współpracy w ramach Inicjatywy Trójmorza za pomocą takiego podejścia napotyka jednak na szereg trudności. Wspólny interes dwunastu państw Europy Środkowo-Wschodniej, wskazywany w trzech dotychczas przyjętych deklaracjach, jest wąski. Współpraca w sferze energetycznej, przedstawiana jako jeden z filarów tego projektu, może okazać się nietrwała w obliczu działań Rosji, która umiejętnie wykorzystuje rozbieżności

40 Zob. P. Bajda, Małe państwo europejskie na arenie międzynarodowej. Polityka zagraniczna Republiki Stowackiej w latach 1993-2016, Ośrodek Myśli Politycznej, Wydawnictwo Naukowe UKSW, Kraków-Warszawa 2018. 
interesów między państwami regionu i rozgrywa je między sobą. We wspólnym interesie wszystkich krajów Trójmorza leży rozwój infrastruktury transportowo-komunikacyjnej na linii północ-południe, ale relatywne zyski dla części z nich będą większe, a dla innych mniejsze, co w praktyce może utrudniać współpracę między wszystkimi dwunastoma partnerami.

Teoria realizmu przyznaje prymat sferze politycznej, natomiast $\mathrm{w}$ deklaracjach odnośnie do Trójmorza akcent został przesunięty na wymiar gospodarczy. Orędownikiem takiego wąskiego zakresu projektu były władze Austrii, które ustami ambasadora Thomasa Buchsbauma głosiły, że „Trójmorze to inicjatywa infrastrukturalna, nie polityczna"41. Z drugiej strony w wielu wypowiedziach podkreślano znaczenie tego projektu w wymiarze bezpieczeństwa i polityki międzynarodowej. Na otwarciu forum w Dubrowniku w 2016 r. gen. Jones akcentował, że inicjatywa zwiększy bezpieczeństwo północnej, środkowej i wschodniej Europy ${ }^{42}$. Na szczycie w Bukareszcie wiele uwagi poświęcono wzmocnieniu całej wspólnoty transatlantyckiej i relacjom z USA, co może okazać się najsilniejszym spoiwem Trójmorza. Dla państw Europy Środkowo-Wschodniej ład transatlantycki wydaje się znacznie bezpieczniejszy niż będący rezultatem jego rozpadu świat postatlantycki. Ewentualne dalsze niekorzystne zmiany obecnego porządku międzynarodowego i będący ich konsekwencją wzrost poczucia zagrożenia mogą prowadzić do wzmocnienia wymiaru politycznego Inicjatywy Trójmorza jako narzędzia budowania relacji Europy Środkowo-Wschodniej z USA. W takich okolicznościach zwiększy się rola teorii realizmu w wyjaśnianiu motywów tej współpracy.

Na obecnym etapie Trójmorze nie ma wyraźnie sprecyzowanych długofalowych celów politycznych, a jego dalszy kształt będzie w dużej mierze zależny od rozwoju sytuacji międzynarodowej. Na razie jest to luźny projekt, który formalnie w żaden sposób nie wpływa na architekturę bezpieczeństwa ani nie przekłada się na konkretne osiągnięcia; ma jednak duży potencjał ze względu na zainteresowanie USA. Scenariusze rozwoju Inicjatywy Trójmorza mogą

41 Zob. wywiad Aureliusza M. Pędziwola z ambasadorem Austrii w Polsce Thomasem Buchsbaumem: Austriacki dyplomata: Trójmorze to inicjatywa infrastrukturalna, nie polityczna, „Deutsche Welle” [online], 11 VII 2017 [dostęp: 12 X 2018], dostępny $\mathrm{w}$ internecie: <www.dw.com/p1/austriacki-dyplomata-tr\%C3\%B3jmorze-to-inicjatywa-infrastrukturalna-nie-polityczna/a-39630402>.

42 Remarks by general James L. Jones, Jr. at the Dubrovnik Three Seas Initiative presidential roundtable, „Atlantic Council” [online], 25 VIII 2016 [dostęp: 12 X2018], dostępny w internecie: <www.atlanticcouncil.org/news/transcripts/remarks-by-general-james-1--ones-jr-at-the-dubrovnik-three-seas-initiative-presidential-roundtable>. 
być skrajnie różne - od jej marginalizacji do budowy przy wsparciu USA nowej struktury politycznej w Europie Środkowo-Wschodniej.

\section{Bibliografia}

Austriacki dyplomata: Trójmorze to inicjatywa infrastrukturalna, nie polityczna, „Deutsche Welle" [online], 11 VII 2017 [dostęp: 12 X 2018], dostępny w internecie: <www.dw.com/pl/ austriacki-dyplomata-tr\%C3\%B3jmorze-to-inicjatywa-infrastrukturalna-nie-polityczna/ a-39630402>.

Bajda P., Małe państwo europejskie na arenie międzynarodowej. Polityka zagraniczna Republiki Słowackiej w latach 1993-2016, Ośrodek Myśli Politycznej, Wydawnictwo Naukowe UKSW, Kraków-Warszawa 2018.

Belgijski dziennik o Trójmorzu: Polska próbuje zjednoczyć region, „TVN 24” [online], 5 VII 2017 [dostęp: 12 X 2018], dostępny w internecie: <www.tvn24.pl/wiadomosci-ze-swiata,2/le-soir-o-trojmorzu-polska-probuje-zjednoczyc-region,754456.html $>$.

Borkowski P.J., Polityczne teorie integracji międzynarodowej, Difin, Warszawa 2007.

Clemente J., Six threats for the U.S. liquefied natural gas business, „Forbes” [online], 15 V 2015

[dostęp: 12 X 2018], dostępny w internecie: <www.forbes.com/sites/judeclemente/2016/05/

15/six-threats-for-the-u-s-liquefied-natural-gas-business/\#448f00413a1b>.

„Cooperation between China and Central and Eastern European Countries” [online, dostęp:

12 X 2018], dostępny w internecie: <www.china-ceec.org/eng/>.

Czaputowicz J., Mapa współczesnego realizmu: realizm klasyczny, neorealizm, realizm neoklasyczny, [w:] Teoria realizmu $w$ nauce o stosunkach międzynarodowych, red. J. Czaputowicz, E. Haliżak, PTSM, Rambler, Warszawa 2014, dostępny w internecie [dostęp: 12 X 2018]: <http://ptsm.edu.pl/wp-content/uploads/publikacje/teoria-realizmuw-nauce-o-stosunkach-miedzynarodowych/J.Czaputowicz.pdf $>$.

Czaputowicz J., Teorie stosunków międzynarodowych. Krytyka i systematyzacja, Wydawnictwo Naukowe PWN, Warszawa 2008.

Dahl M., Inicjatywa Trójmorza z perspektywy niemieckiej, „Studia Europejskie” 2018, nr 2 (86). Discours du Président Jean-Claude Juncker au sommet de l'Initiative des Trois Mers, „European Commission" [online, dostęp: 12 X 2018], dostępny w internecie: <http://europa.eu/rapid/ press-release_SPEECH-18-5825_fr.htm>.

Dubrownik Forum 2016. „, Strengthening Europe: connecting north and south”, ,Ministarstvo vanjskih i europskih poslova" [online, dostęp: 12 X 2018], dostępny w internecie: $<$ http:// www.mvep.hr/files/file/2016/1608222-dubrovnik-forum-draft-program.pdf>.

Gniazdowski M., Trójmorze - nowy instrument $w$ polskiej polityce zagranicznej, „Polski Przegląd Dyplomatyczny” 2017, nr 4 (71).

Grieco J.M., State interests and institutional rule trajectories. A neorealist interpretation of the Maastricht treaty and European economic and monetary union, „Security Studies” 1996, vol. 5. Guzzini S., Realizm w nauce o stosunkach międzynarodowych, Scholar, Warszawa 2017.

Jackson R., Sørensen G., Wprowadzenie do stosunków międzynarodowych. Teorie i kierunki badawcze, Wydawnictwo Uniwersytetu Jagiellońskiego, Kraków 2012.

Joint declaration of the Third Summit of the Three Seas Initiative (Bucharest, 17-18 September 2018), „3 Seas Initiative Summit” [online, dostęp: 12 X 2018], dostępny w internecie: 
<www.three-seas.eu/wp-content/uploads/2018/09/BUCHAREST-SUMMIT-JOINTDECLARATION.pdf $>$.

Kaczmarski M., Realizm neoklasyczny, [w:] Teorie i podejścia badawcze w nauce o stosunkach międzynarodowych, red. R. Zięba, S. Bieleń, J. Zając, Wydział Dziennikarstwa i Nauk Politycznych UW, Warszawa 2015.

Kałan D., Trójkąt sławkowski: konkurencja dla Wyszehradu?, Polski Instytut Spraw Międzynarodowych, 16 II 2015 (Biuletyn PISM, 18 (1255)), dostępny w internecie [dostęp: 12 X 2018]: <www.pism.pl/files/?id_plik=19250>.

Kowal P., Czwarte Międzymorze?, „Obóz” 2016, nr 54.

Kowal P., Orzelska-Stączek A., Inicjatywa Trójmorza. Geneza, cele i funkcjonowanie, Instytut Studiów Politycznych PAN, Warszawa 2019.

Kuczkiewicz J., La „,nouvelle Europe” se réunit à 12 pour recevoir chaleureusement Donald Trump, „Le Soir” [online], 5 VII 2017 [dostęp: 12 X 2018], dostępny w internecie: $<$ http://plus.lesoir.be/103076/article/2017-07-05/la-nouvelle-europe-se-reunit-12-pour-recevoir-chaleureusement-donald-trump $>$.

Legro J.W., Moravcsik A., Is anybody still a realist?, „International Security” 1999, vol. 24, No. 2, dostępny w internecie [dostęp: 12 X 2018]: <https://www.princeton.edu/ amoravcs/library/anybody.pdf $>$.

Mearsheimer J.J., Back to the future: instability in Europe after the Cold War, „International Security" 1990, vol. 15, No. 1, dostępny w internecie [dostęp: 12 X 2018]: <http://mearsheimer.uchicago.edu/pdfs/A0017.pdf $>$.

Military expenditure by country, in constant (2015) US\$ m., „Stockholm International Peace Research Insitute" [online, dostęp: 12 X 2018], dostępny w internecie: <www.sipri.org/ sites/default/files/Milex-constant-2015-USD.pdf>.

Minister Szczerski: Polska chce być silnym partnerem euroatlantyckiej wspólnoty, „Prezydent” [online], 17 IX 2018 [dostęp: 12 X 2018], dostępny w internecie: <www.prezydent.pl/ kancelaria/aktywnosc-ministrow/art,1358,minister-szczerski-polska-chce-byc-silnympodmiotem-euroatlantyckiej-wspolnoty.html>.

Morgenthau H., Polityka między narodami. Walka o potęgę i pokój, Difin, Warszawa 2010.

Narizny K., On systemic paradigms and domestic politics. A critique of the newest realism, „International Security” 2017, vol. 42, issue 2.

National Security Strategy of the United States of America. December 2017, „The White House” [online, dostęp: 12 X 2018], dostępny w internecie: <https:/www.whitehouse.gov/wp-content/uploads/2017/12/NSS-Final-12-18-2017-0905.pdf $>$.

Niemcy chca do Trójmorza. „Nowa polityka wschodnia”, „Deutsche Welle” [online], 19 IX 2018 [dostęp: 12 X 2018], dostępny w internecie: <www.dw.com/pl/niemcy-chc\%C4\%85-do-tr\%C3\%B3jmorza-nowa-polityka-wschodnia/a-45549145>.

Niemcy o sporze UE z Polską: Chodzi o wolność, „Rzeczpospolita”, 19 X 2018.

Orzelska-Stączek A., Bezpieczeństwo Europy Środkowo-Wschodniej w perspektywie ładu globalnego ze szczególnym uwzględnieniem roli Polski, [w:] System euroatlantycki w wielobiegunowym ładzie międzynarodowym, red. J. Fiszer, Instytut Studiów Politycznych PAN, Warszawa 2013.

Polska jest pierwsza linią obrony NATO, „Rzeczpospolita” [online], 10 XI 2018 [dostęp: 21 XI 2018], dostępny w internecie: <http://archiwum.rp.pl/artykul/1389928-Polska-jest-pierwsza-linia-obrony-NATO.html $>$. 
Polska poparła wniosek Niemiec o status państwa partnerskiego Inicjatywy Trójmorza, „Prezydent” [online], 28 VIII 2018 [dostęp: 12 X 2018], dostępny w internecie: <www. prezydent.pl/kancelaria/aktywnosc-ministrow/art,1311,polska-poparla-wniosek-niemieco-status-panstwa-partnerskiego-inicjatywy-trojmorza.html>.

Remarks by general James L. Jones, Jr. at the Dubrovnik Three Seas Initiative presidential roundtable, „Atlantic Council” [online], 25 VIII 2016 [dostęp: 12 X 2018], dostępny w internecie: <www.atlanticcouncil.org/news/transcripts/remarks-by-general-james-l-jones-jr-at-the-dubrovnik-three-seas-initiative-presidential-roundtable $>$.

Rotaru V., Umland A., How Romania and Poland can strengthen NATO and the EU. Two new cooperation initiatives could improve regional security, „Foreign Affairs” [online], 10 XI 2017 [dostęp: 12 X 2018], dostępny w internecie: <www.foreignaffairs.com/articles/ central-europe/2017-11-10/how-romania-and-poland-can-strengthen-nato-and-eu>.

Schweller R.L., Pu X., After unipolarity China's visions of international order in an era of U.S. decline, „International Security” 2011, vol. 36, No. 1.

The Second Summit of the 3 Seas Initiative Joint Declaration, „3 Seas Initiative Summit” [online, dostęp: 12 X 2018], dostępny w internecie: <www.three-seas.eu/wp-content/uploads/ 2018/06/WARSAW.pdf $>$.

Security council approves 'no-fly zone' over Libya, authorizing 'all necessary measures' to protect civilians, by vote of 10 in favour with 5 abstentions, „United Nations” [online], 17 III 2011 [dostęp: 12 X 2018], dostępny w internecie: <http://www.un.org/News/Press/ docs/2011/sc10200.doc.htm>.

Sienkiewicz M., Koncepcja Trójmorza w polityce zagranicznej Polski po 2015 r., ,, Dyplomacja i Bezpieczeństwo" 2016, nr 1.

Snyder J., One world, rival theories, „Foreign Policy” 2004, No. 145.

Stępniewski T., Inicjatywa Trójmorza: uwarunkowania geopolityczne i nowy model regionalnej wspótpracy, „Studia Europejskie” 2018, nr 2 (86).

System euroatlantycki $w$ wielobiegunowym ładzie międzynarodowym, red. J. Fiszer, Instytut Studiów Politycznych PAN, Warszawa 2013.

Szczerski K., Utopia europejska: kryzys integracji i polska inicjatywa naprawy, Biały Kruk, Kraków 2017.

Teoria realizmu $w$ nauce o stosunkach międzynarodowych, red. J. Czaputowicz, E. Haliżak, PTSM, Rambler, Warszawa 2014.

Teorie i podejścia badawcze w nauce o stosunkach międzynarodowych, red. R. Zięba, S. Bieleń, J. Zając, Wydział Dziennikarstwa i Nauk Politycznych UW, Warszawa 2015.

Ukielski P., Mapa Trójmorza. Przegląd punktów wspólnych i rozbieżności w polityce 12 państw regionu, Centrum Analiz Klubu Jagiellońskiego 2016 (Raport, 3/2016).

U.S. Secretary of Energy Rick Perry at the Three Seas Initiative Business Forum, „U.S. Embassy in Romania" [online], 20 IX 2018 [dostęp: 12 X 2018], dostępny w internecie: <https://ro.usembassy.gov/secretary-of-energy-rick-perry-at-the-three-seas-initiative-business-forum/>.

Więcławski J., Hans Morgenthau, realizm klasyczny i jego rekomendacje dla polskiej polityki zagranicznej, „Myśl Ekonomiczna i Polityczna” 2011, nr 3 (34).

Więcławski J., Teoria realizmu Hansa J. Morgenthaua: koncepcje, krytyka i znaczenie dla wspótczesnych stosunków międzynarodowych, Instytut Nauk Politycznych Uniwersytetu Warmińsko-Mazurskiego, Olsztyn 2014.

Wiśniewski B., Szczyt Inicjatywy Trójmorza w Bukareszcie - wizja nabiera kształtu, „Komentarz PISM" 2018, nr 64. 
Wojciuk A., Czaputowicz J., Realizm w polskiej nauce o stosunkach międzynarodowych, [w:] Teoria realizmu w nauce o stosunkach międzynarodowych, red. J. Czaputowicz, E. Haliżak, PTSM, Rambler, Warszawa 2014.

Wróbel A., Polityka handlowa w świetle założeń realizmu, [w:] Teoria realizmu w nauce o stosunkach międzynarodowych, red. J. Czaputowicz, E. Haliżak, PTSM, Rambler, Warszawa 2014.

Wspólna deklaracja w sprawie Inicjatywy Trójmorza, „Prezydent” [online], 25 VIII 2016 [dostęp: 12 X 2018], dostępny w internecie: <www.prezydent.pl/aktualnosci/wizyty-zagraniczne/art,105,wspolna-deklaracja-w-sprawie-inicjatywy-trojmorza.html>.

Wystapienie Prezydenta podczas Forum Biznesowego Trójmorza, „Prezydent” [online], 17 IX 2018 [dostęp: 12 X 2018], dostępny w internecie: <www.prezydent.pl/aktualnosci/wypowiedzi-prezydenta-rp/wystapienia/art,523, wystapienie-prezydenta-podczas-forumbiznesowego-trojmorza.html>.

Zalewski B., Strach to zły doradca dyplomatów od wizji Trójmorza, „RMF 24” [online], 6 VII 2017 [dostęp: 12 X 2018], dostępny w internecie: <www.rmf24.pl/fakty/swiat/ news-strach-to-zly-doradca-dyplomatow-od-wizji-trojmorza,nId,2413717>.

Żurawski vel Grajewski P., Baeva Motusić A., Redlowska K., Adriatic - Baltic - Black Sea. Visions of cooperation, Instytut Studiów Wschodnich, Warszawa 2017, dostępny w internecie [dostęp: 12 X 2018]: <http://www.forum-ekonomiczne.pl/wp-content/uploads/2017/08/ Adriatyk-Ba\%C5\%82tyk-Morze-Czarne16x24_2017en_PDF.pdf $>$. 